\title{
DNA-Dependent Detection of the Grapevine Fungal Endophytes Aureobasidium pullulans and Epicoccum nigrum
}

\author{
M. Martini, R. Musetti, S. Grisan, R. Polizzotto, S. Borselli, F. Pavan, and R. Osler, Department of "Biologia e \\ Protezione delle Piante", University of Udine, Via delle Scienze 208, 33100 Udine, Italy
}

\begin{abstract}
Martini, M., Musetti, R., Grisan, S., Polizzotto, R., Borselli, S., Pavan, F., and Osler, R. 2009. DNA-dependent detection of the grapevine fungal endophytes Aureobasidium pullulans and Epicoccum nigrum. Plant Dis. 93:993-998.

Aureobasidium pullulans and Epicoccum nigrum are frequently reported as endophytes of various crops, including grapevine (Vitis vinifera). Because of their potential role as biological control agents against grapevine pathogens, we examined the occurrence of A. pullulans and $E$. nigrum in two grapevine varieties (Merlot and Prosecco) in Italian vineyards where spontaneous recovery from phytoplasma disease is recurrent. Species-specific primers for A. pullulans and two genetically distinct strains of $E$. nigrum were designed in variable regions of ITS1 and ITS2. Primer specificity was confirmed by polymerase chain reaction using purified DNA from other fungal endophytes that are usually encountered during isolation attempts from grapevine tissues and from several other strains of A. pullulans and E. nigrum isolated from other sources. In order to determine the occurrence of the two endophytes in grapevine plants, DNA was extracted from shoots of 44 grapevines collected in six vineyards from different localities of northeast Italy. Both endophytes were detected and their identity was confirmed by restriction fragment length polymorphism (RFLP) patterns obtained from reference strains. RFLP analyses confirmed the presence of two E. nigrum strains belonging to different RFLP groups in grapevine. The molecular methods described allowed a sensitive, specific, and reliable identification of the two endophytes in grapevine.
\end{abstract}

Aureobasidium pullulans (de Bary) Arnaud is a widespread epiphyte well adapted to the phyllosphere and carposphere. Some A. pullulans isolates exhibit antagonistic activity against a number of phytopathogenic fungi $(33,34)$, competing for nutrients and space and producing numerous compounds such as pectolytic enzymes (28), antimicrobial metabolites (36), and high-molecular-weight polysaccharides (pullulan) (29). It is therefore used as a biocontrol agent against postharvest pathogens (e.g., Botrytis cinerea and Penicillium expansum) (27,33). Epicoccum nigrum Link is another component of the resident mycoflora on various plants and is a saprophyte on dying plant organs (22). E. nigrum produces a number of secondary metabolites such as epicoccone $(10,17)$ and flavipin, which has antibiotic activity against Monilinia laxa, the causal agent of brown rot $(17,24)$. Inhibition of the grape-

Corresponding author: R. Musetti

E-mail: Rita.Musetti@uniud.it

Accession numbers: EU529993, EU529994, EU529995, EU529996, EU529997, EU529998, EU529999, EU530000, EU530001, EU530002, EU530003, EU530004.

Accepted for publication 9 June 2009.

doi:10.1094/PDIS-93-10-0993

(c) 2009 The American Phytopathological Society vine pathogens Plasmopara viticola and $B$. cinerea has been also reported by $E$. $n i$ grum $(11,13,20)$. Thus, A. pullulans and $E$. nigrum may potentially provide disease control of these important pathogens.

A. pullulans and E. nigrum have been isolated as endophytes from different crops, including grapevine (Vitis vinifera L.) $(5,11,29,30,33)$. In particular, they have been found in leaves (mainly near the midribs; 1,30), berries $(30,34)$, and dormant buds (9). It is recognized that endophytes are of great importance for the hosts, and their role in the protection of the plants against insects, nematodes, and pathogenic microorganisms has been well demonstrated $(4,19,32)$. However, the role of endophytic microorganisms in relation to systemic, incurable diseases, such as those associated with phytoplasmas, has still to be investigated. Spontaneous recovery from phytoplasma-induced symptoms has been reported in grapevines and fruit crops, indicating that a type of resistance could occur in previously infected plants (26). It has been hypothesized that endophytic microorganisms may take part in this resistance phenomenon. In addition, fungi and yeasts associated with grapevines may play an important role in wine fermentation (12).

In order to determine the distribution and frequency of endophytes in host tissues, accurate identification of the organisms is required. Because endophytes do not cause symptoms in their hosts, they are difficult to detect. Conventional methods for identifying fungal endophytes rely on isolation, culturing, and laboratory identification. However, some fungi develop slowly or do not readily grow in culture (25). Other methods used to detect endophytes include histochemical, immunological, and molecular methods (7).

In this study, an efficient DNA extraction method and a sensitive polymerase chain reaction (PCR) protocol were developed for the detection of the grapevine endophytes $A$. pullulans and E. nigrum. In addition, the relationship between the presence of endophytes and the spontaneous recovery from a phytoplasma disease was examined.

\section{MATERIALS AND METHODS}

Plant material. Tissue samples were collected from 10-year-old grapevines ( $V$. vinifera $\mathrm{cv}$. Prosecco) in a vineyard near Montebelluna in the Veneto region of northeastern Italy. Plants in this vineyard had been rated since 2000 for symptoms of phytoplasma diseases (26). Plants were categorized as Flavescence dorée (FD)infected (showing phytoplasma symptoms), healthy (asymptomatic), or recovered (previously symptomatic but now asymptomatic). For the present work, five individual FD-symptomatic grapevines, five asymptomatic plants, and five recovered plants were sampled in October 2005. Five randomly sampled leaves and two 2year-old shoots were collected from each of the plants, stored at $4^{\circ} \mathrm{C}$ in the dark, and processed within $24 \mathrm{~h}$ for fungal endophyte isolation.

Fungal isolates. To isolate endophytes, plant material was washed with water, surface-sterilized by immersion in $3 \%$ sodium hypochlorite for $4 \mathrm{~min}$, and rinsed twice in sterile water for $1 \mathrm{~min}$. Four tissue pieces (about $5 \times 5 \mathrm{~mm}$ ) per leaf or shoot were placed in $90-\mathrm{mm}$ petri dishes containing potato dextrose agar (PDA; Difco, Plymouth, MN) and incubated in a growth chamber for $48 \mathrm{~h}$ at $25^{\circ} \mathrm{C}, 60 \%$ relative humidity, and cold UV light with a photoperiod of $12 \mathrm{~h}$. Any fungal colonies recovered from tissue samples were subcultured five times on fresh PDA plates to obtain pure cultures. Cultures were then maintained on PDA at $4{ }^{\circ} \mathrm{C}$ for short-term storage or stored in sterile $\mathrm{H}_{2} \mathrm{O}$ at room temperature in the dark for longer-term storage. 
DNA extraction. High-molecularweight DNA was extracted from fresh mycelia of the isolated endophytes and from other isolates of $A$. pullulans and $E$. nigrum (Table 1) following a modified procedure of Lecellier and Silar (23). After 7 days of growth, approximately $450 \mathrm{mg}$ of mycelia was harvested from the surface of a sterilized cellophane membrane (BIORAD, Hercules, CA) on PDA with the aid of a sterile spatula. Mycelium was then placed in a sterile mortar with $3 \mathrm{ml}$ of extraction buffer and homogenized with a sterile pestle. One milliliter of the homogenate was placed in a $2-\mathrm{ml}$ microfuge tube, vortexed, frozen for $30 \mathrm{~s}$ in liquid nitrogen, and thawed at $70^{\circ} \mathrm{C}$. The vortexing and freeze/thaw procedure was repeated three times. After centrifugation at $10,000 \mathrm{rpm}$ for $10 \mathrm{~min}$, the supernatant was transferred to another sterile microfuge tube and extracted twice with an equal volume of phenol:chloroform: isoamyl alcohol $(25: 24: 1)$ and with an equal volume of chloroform:isoamyl alcohol (24:1). Following centrifugation at $8,000 \mathrm{rpm}$ for $10 \mathrm{~min}$, the supernatant was transferred to another sterile microfuge tube, and $2 / 3$ volume of cold isopropanol was added and gently mixed by inverting several times. The tubes were then centrifuged at $12,000 \mathrm{rpm}$ for $15 \mathrm{~min}$ at $4^{\circ} \mathrm{C}$ to pellet the DNA, which was washed with $0.5 \mathrm{ml}$ of cold $70 \%$ ethanol after removal of the supernatant. Following centrifugation $\left(12,000 \mathrm{rpm}\right.$ for $5 \mathrm{~min}$ at $\left.4^{\circ} \mathrm{C}\right)$, the supernatant was discarded. The DNA pellets were then dried by a HetoVac vacuum and dissolved in $400 \mu \mathrm{l}$ of TE buffer. Further DNA purification was carried out by DNA precipitation with $1 / 10$ volume of 3 $\mathrm{M}$ sodium acetate at $\mathrm{pH} 5.2$ and 2 volumes of cold $95 \%$ ethanol with gentle mixing. Following centrifugation (14,000 rpm for 5 min at $4^{\circ} \mathrm{C}$ ), the supernatant was discarded and the DNA pellet was washed twice with $1 \mathrm{ml}$ of $70 \%$ ethanol followed by a wash with $1 \mathrm{ml}$ of $80 \%$ ethanol. After centrifugation, the DNA pellet was dried with a HetoVac vacuum, suspended in $100 \mu$ of TE buffer, and treated with RNase A for 1 $\mathrm{h}$ at $37^{\circ} \mathrm{C}$. DNA concentrations were determined with a spectrophotometer (Beckman Inc., Fullerton, CA).

Amplification and sequencing. The nuclear rDNA internal transcribed spacer regions (ITS1 and ITS2) and the 5.8S rRNA gene from all the endophytes, in- cluding one A. pullulans and the two $E$. nigrum isolates, were amplified by PCR with the universal primers ITS1 and ITS4 (38). The extracted DNA was diluted 1:50 in sterile water to obtain a concentration of

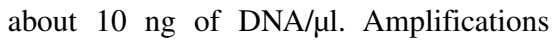
were performed with an automated thermal cycler (MJ Research DNA Thermal Cycler PTC-100) in 25- $\mu$ l reactions containing $200 \mu \mathrm{M}$ each of the four dNTPs, $0.4 \mu \mathrm{M}$ of each primer, $1.5 \mathrm{mM} \mathrm{MgCl}_{2}, 0.625$ units of DNA polymerase, POLYTAQ (Polymed, Florence, Italy), and $1 \mu \mathrm{l}$ of 1:50 diluted DNA. The PCR program consisted of 38 cycles: denaturation at $94^{\circ} \mathrm{C}$ for $1 \min (2$ min for the first cycle), annealing at $54^{\circ} \mathrm{C}$ for $1 \mathrm{~min}$, and extension at $72^{\circ} \mathrm{C}$ for $1 \mathrm{~min}$ (10 min for the last cycle). Five microliters of the amplified products were visualized by electrophoresis through a $1 \%$ agarose gel stained in ethidium bromide.

The ITS1/ITS4 PCR products (about 500 to $600 \mathrm{bp}$ ) were purified using a Wizard SV Gel and the PCR Clean-Up System Kit (Promega, Madison, WI, USA). Sequencing was performed with an automated DNA sequencer (ABI Prism Model 3730) at the Genelab (ENEA Casaccia, Rome, Italy) using the ITS4 primer. The

Table 1. Source of fungal isolates included in this study

\begin{tabular}{|c|c|c|c|c|}
\hline Fungal species $^{\mathrm{a}}$ & Isolate code & GenBank accession no. & Host plant & Location (Italian province) \\
\hline Aureobasidium pullulans ${ }^{\mathrm{b}}$ & R6T4 & EU529999 & Vitis vinifera & Montebelluna (TV) \\
\hline Epicoccum nigrum $^{\mathrm{b}}$ & $\mathrm{H} 2 \mathrm{~F} 1$ & EU529998 & Vitis vinifera & Montebelluna (TV) \\
\hline Epicoccum nigrum ${ }^{\mathrm{b}}$ & R11T3 & EU530001 & Vitis vinifera & Montebelluna (TV) \\
\hline Alternaria alternata ${ }^{\mathrm{b}}$ & T65A & EU530004 & Vitis vinifera & Montebelluna (TV) \\
\hline Arthrinium saccharib & H5T3 & EU529997 & Vitis vinifera & Montebelluna (TV) \\
\hline Leptosphaerulina chartarum ${ }^{\mathrm{b}}$ & $\mathrm{R} 4 \mathrm{~F} 1$ & EU529996 & Vitis vinifera & Montebelluna (TV) \\
\hline Nigrospora oryzae ${ }^{\mathrm{b}}$ & H5T4 & EU529995 & Vitis vinifera & Montebelluna (TV) \\
\hline Nigrospora oryzae $^{\mathrm{b}}$ & $\mathrm{R} 11 \mathrm{~F} 1$ & EU529994 & Vitis vinifera & Montebelluna (TV) \\
\hline Nigrospora oryzae $^{\mathrm{b}}$ & $\mathrm{R} 4 \mathrm{~F} 3$ & EU529993 & Vitis vinifera & Montebelluna (TV) \\
\hline Phoma sp. ${ }^{\mathrm{b}}$ & $\mathrm{P} 45 \mathrm{~A}$ & EU530003 & Vitis vinifera & Montebelluna (TV) \\
\hline Phomopsis sp. ${ }^{\mathrm{b}}$ & $\mathrm{R} 42$ & - & Vitis vinifera & Montebelluna (TV) \\
\hline Schizophyllum commune $e^{\mathrm{b}}$ & R6T2 & EU530002 & Vitis vinifera & Montebelluna (TV) \\
\hline Sclerotinia sclerotiorum $^{\mathrm{b}}$ & $\mathrm{H} 3 \mathrm{~F} 2$ & EU530000 & Vitis vinifera & Montebelluna (TV) \\
\hline Aureobasidium pullulans ${ }^{\mathrm{c}}$ & VIF1a & - & Vitis vinifera & Monopoli (BA) \\
\hline Aureobasidium pullulans ${ }^{\mathrm{c}}$ & VIfg1a & - & Vitis vinifera & Monopoli (BA) \\
\hline Aureobasidium pullulans ${ }^{\mathrm{c}}$ & PFla & - & Prunus domestica & Senigallia (AN) \\
\hline Aureobasidium pullulans ${ }^{\mathrm{c}}$ & Nfgla & - & Juglans regia & Ancona (AN) \\
\hline Aureobasidium pullulans ${ }^{\mathrm{c}}$ & NF1a & - & Juglans regia & Ancona (AN) \\
\hline Aureobasidium pullulans ${ }^{\mathrm{c}}$ & PEF1a & - & Pyrus communis & Monopoli (BA) \\
\hline Aureobasidium pullulans ${ }^{\mathrm{c}}$ & PTfg1a & - & Pittosporum spp. & Ancona (AN) \\
\hline Aureobasidium pullulans ${ }^{\mathrm{c}}$ & AFla & - & Prunus armeniaca $\mathrm{L}$. & Senigallia (AN) \\
\hline Aureobasidium pullulans ${ }^{\mathrm{c}}$ & MF1a & - & Morus spp. & Ancona (AN) \\
\hline Aureobasidium pullulans ${ }^{\mathrm{c}}$ & POMF1a & - & Lycopersicum esculentum & Monopoli (BA) \\
\hline Epicoccum nigrum $^{\mathrm{d}}$ & E (IPV) & - & Zea mays & Milano (MI) \\
\hline Epicoccum nigrum ${ }^{\mathrm{e}}$ & E1 & - & Quercus cerris & Firenze (FI) \\
\hline Epicoccum nigrum ${ }^{\mathrm{e}}$ & E3 & - & Quercus cerris & Firenze $(\mathrm{FI})$ \\
\hline Epicoccum nigrum ${ }^{\mathrm{f}}$ & EPV1 & - & Oryza sativa & Pavia (PV) \\
\hline Epicoccum nigrum ${ }^{\mathrm{f}}$ & EPV2 & - & Phragmites australis & Pavia (PV) \\
\hline Epicoccum nigrumg & 1POL1B1 & - & Malus mali & Polcenigo (PN) \\
\hline Epicoccum nigrum & $\mathrm{DC} 1 \mathrm{~Pa}$ & - & Malus mali & Pantianicco (UD) \\
\hline Epicoccum nigrum ${ }^{\mathrm{g}}$ & DD20.1En & - & Malus mali & Enemonzo (UD) \\
\hline Epicoccum nigrum ${ }^{\mathrm{g}}$ & DD8En & - & Malus mali & Enemonzo (UD) \\
\hline Epicoccum nigrum ${ }^{\mathrm{g}}$ & DDFannaS04 & - & Malus mali & Fanna (PN) \\
\hline
\end{tabular}

a Isolates of Epicoccum nigrum were further characterized into restriction fragment length polymorphism (RFLP) groups: isolates H2F1, E1, EPV1, 1POL1B1, DD20.1En, DD8En, and DDFannaS04 were designated group A; and R11T3, E (IPV), E3, EPV2, and DC1Pa were designated group B.

b Isolated from grapevine in this study and maintained at the Department of "Biologia e Protezione delle Piante", University of Udine, Italy.

c Provided by G. Romanazzi, University of Ancona, Italy (18).

d Provided by G. Assante, University of Milano, Italy.

e Provided by S. Moricca, University of Firenze, Italy (37).

${ }^{\mathrm{f}}$ Provided by M. Rodolfi, University of Pavia, Italy.

g Provided by S. Moruzzi and maintained at the Department of "Biologia e Protezione delle Piante", University of Udine, Italy. 
obtained nucleotide sequences were compared with those present in GenBank. The nucleotide sequences were deposited in GenBank (Table 1).

Primer design. DNA sequences of $A$. pullulans and $E$. nigrum strains obtained in this study were aligned with sequences of $A$. pullulans and E. nigrum strains and other closely related fungal species deposited in GenBank $(2,39,40)$ using the NCBI BLASTn 2.2.20 program. The multiple alignments were generated with the output option "flat query-anchored with identities". Primers specific for A. pullulans were designed in ITS2 regions that were conserved among A. pullulans strains. Primers specific for E. nigrum were designed in ITS regions. Species-specific PCR primers were developed using software Primer3 (31). Primers for A. pullulans were named Apu(R6T4)F2 (5'-GCT ATG CTT GGT ATT GGG CGT3')/Apu(R6T4)R2 (5'-AAA GGT TTC AGT CGG CAG AGT T-3'), and primers specific for $E$. nigrum were named Eni(H2F1)F1 (5'-CCT AGA GTT TGT AGA CTT CGG T-3')/Eni(H2F1)R1 (5'GAC GTC GTC GTT ATG AGT G-3').

Specificity of the primers for A. pullulans and E. nigrum was assessed by PCR using $10 \mathrm{ng}$ of purified DNA from A. pullulans (R6T4 isolate), E. nigrum (both $\mathrm{H} 2 \mathrm{~F} 1$ and R11T3 isolates), and 10 other grapevine endophytes. The specificity of the primers was also tested against other $A$. pullulans strains provided by G. Romanazzi (University of Marche, Italy) (18) and other E. nigrum strains maintained in our collection, or provided by M. Rodolfi (University of Pavia, Italy), G. Assante (University of Milano, Italy), and S. Moricca (University of Firenze, Italy) (37). These strains were isolated from several hosts with different geographic origins in Italy (Table 1). PCR reactions were identical to those described above for A. pullulans, but slightly adjusted for $E$. nigrum $(0.3 \mu \mathrm{M}$ of forward primer and $1.3 \mathrm{mM}$ $\mathrm{MgCl}_{2}$ ). Amplification conditions included an initial denaturation of $2 \mathrm{~min}$ at $94^{\circ} \mathrm{C}$ followed by 40 cycles of $40 \mathrm{~s}$ at $94^{\circ} \mathrm{C}, 20 \mathrm{~s}$ at $60^{\circ} \mathrm{C}$ (for E. nigrum) or $30 \mathrm{~s}$ at $57^{\circ} \mathrm{C}$ (for A. pullulans), and $40 \mathrm{~s}$ at $72^{\circ} \mathrm{C}$ with a final extension of $72^{\circ} \mathrm{C}$ for $8 \mathrm{~min}$. Five microliters of the amplicons were visualized after electrophoresis through a 1 or $1.5 \%$ agarose gel as previously described.

The sensitivity of the species-specific PCR assays was determined by testing 10fold serial dilutions $(50 \mathrm{ng} / \mu \mathrm{l}$ to $5 \mathrm{fg} / \mu \mathrm{l})$ of genomic DNA preparations of A. pullulans isolate R6T4 and E. nigrum isolate $\mathrm{H} 2 \mathrm{~F} 1$. Serial dilutions were prepared either in molecular grade water or in $20 \mathrm{ng} / \mu \mathrm{l}$ of total DNA from endophyte-free micropropagated grapevine tissue (cv. Chardonnay) to confirm that the presence of plant DNA would not interfere with the PCR reactions. The micropropagated grapevines were provided by Massimo Gardiman from Centro di Ricerca per la Viticoltura (CRA-VIT, Conegliano TV, Italy).

Detection of $A$. pullulans and $E$. nigrum in plant tissue. Reliability of the primers was verified on 44 grapevine samples (cultivars Prosecco and Merlot) collected in October 2007 and 2008 from six different vineyards located in Treviso (Montebelluna) and Pordenone (Caneva, Fiaschetti, Vigonovo, Nave, Fontanafredda) provinces in Italy, where recovery from Flavescence dorèe is recurrent. Two 2-year-old shoots were collected for each grapevine that was either symptomatic for phytoplasma infection, healthy, or recovered. DNA was extracted from branch internodes following a modified version of the procedure described by Doyle and Doyle (8). Shoots were sterilized as described above, and the outer layer was aseptically removed to avoid contamination of the samples $(14,35)$. One gram of vascular tissue from each shoot sample was ground in a sterile mortar with liquid nitrogen. Five milliliters of $2.5 \%$ CTAB buffer (100 mM Tris pH 8.0; $1.4 \mathrm{M}$ $\mathrm{NaCl} ; 50$ mM EDTA pH 8.0; 2.5\% CTAB; $1 \% \quad$ PVP-40; $0.2 \%$ 2-mercaptoethanol added before use), previously heated in a water bath at $65^{\circ} \mathrm{C}$, was added to the pulverized tissue. One milliliter of the homogenate was transferred to a sterile $2-\mathrm{ml}$ tube, incubated at $65^{\circ} \mathrm{C}$ for $30 \mathrm{~min}$, and extracted with an equal volume of chloroform:isoamyl alcohol (24:1). Following centrifugation at $13,000 \mathrm{rpm}$ for $15 \mathrm{~min}$ at $4^{\circ} \mathrm{C}$, the supernatant was transferred to another sterile microfuge tube, and 2/3 volume of cold isopropanol was added and gently mixed by inverting several times. Tubes were centrifuged at $13,000 \mathrm{rpm}$ for
10 min at $4{ }^{\circ} \mathrm{C}$ to pellet the DNA. The final steps in the procedure were conducted as previously described.

The presence of A. pullulans and E. nigrum was assessed by direct-PCR with species-specific primers following the PCR conditions previously described and using about $20 \mathrm{ng}$ of total genomic DNA. In case of negative results, a nested-PCR procedure was adopted in which the first PCR run was performed with the universal fungal primer pair ITS1/ITS4 (15) followed by nested-PCR with specific primer pairs after 1:30 dilution. Direct-PCR with ITS1/ITS4 was performed with the reaction conditions described above with the following cycling parameters: an initial denaturation $\left(2 \mathrm{~min}\right.$ at $\left.94^{\circ} \mathrm{C}\right)$ followed by 30 cycles of $1 \mathrm{~min}$ at $94^{\circ} \mathrm{C}, 1 \mathrm{~min}$ at $52^{\circ} \mathrm{C}$, and $1 \mathrm{~min}$ at $72^{\circ} \mathrm{C}$, with a final extension of $72^{\circ} \mathrm{C}$ for $8 \mathrm{~min}$. Nested-PCR reactions of 36 cycles with specific primer pairs were conducted following the conditions previously described. Purified DNA from A. pullulans $\mathrm{R} 6 \mathrm{~T} 4$ and E. nigrum $\mathrm{H} 2 \mathrm{~F} 1$ and R11T3 were used as reference strains.

To confirm the identity of the PCR products amplified with Apu(R6T4)F2/R2 and Eni(H2F1)F1/R1 primer pairs, restriction fragment length polymorphism (RFLP) analysis was performed. About 6 $\mu \mathrm{l}$ of $\mathrm{Apu}(\mathrm{R} 6 \mathrm{~T} 4) \mathrm{F} 2 / \mathrm{R} 2$ products was digested individually with Tru1I and $B s u$ RI (Fermentas, Lithuania) restriction enzymes, and $6 \mu \mathrm{l}$ of the Eni(H2F1)F1/R1 products was digested individually with Tru1I and Hin6I (Fermentas, Lithuania). The digested products were then separated by electrophoresis through an $8 \%$ polyacrylamide gel in $1 \times$ TBE buffer, stained, and visualized as above. The RFLP pro-
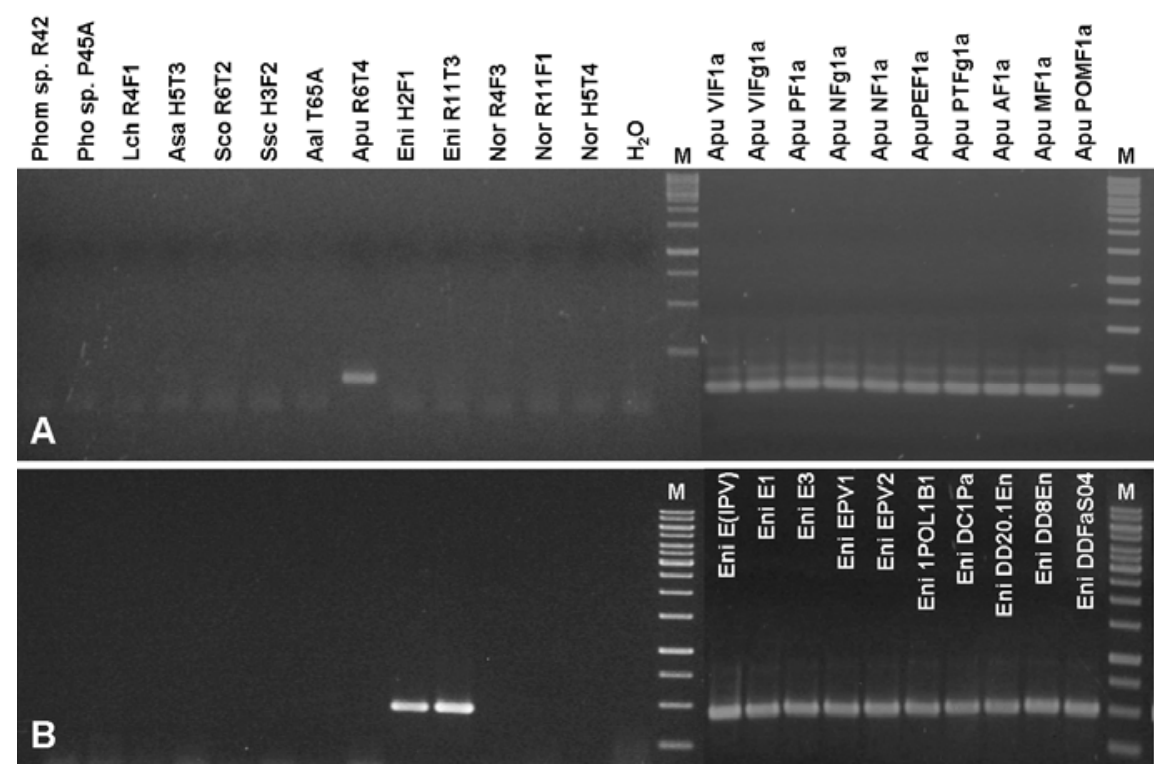

Fig. 1. Agarose gel of polymerase chain reaction (PCR) products obtained with species-specific primers A, Apu(R6T4)F2/R2 and B, Eni(H2F1)F1/R1. Aal: Alternaria alternata; Apu: Aureobasidium pullulans; Asa: Arthrinium sacchari; Eni: Epicoccum nigrum; Nor: Nigrospora oryzae; Pho: Phoma sp.; Phom: Phomopsis sp.; Sco: Schizophyllum commune; Ssc: Sclerotinia sclerotiorum; Lch: Leptosphaerulina chartarum. M: $1 \mathrm{~kb}$ DNA ladder (bottom to top: 250 to 10,000 bp). 
files obtained from grapevine samples were compared with those from the $A$. pullulans $\mathrm{R} 6 \mathrm{~T} 4$ and $E$. nigrum $\mathrm{H} 2 \mathrm{~F} 1$ and R11T3 reference strains. The same RFLP analysis was performed on PCR products obtained with species-specific primers from all $A$. pullulans and E. nigrum isolates.

\section{RESULTS}

Fungal isolates. Ninety-four fungal endophytes, representing 26 morphotypes, were obtained from leaf and shoot materials sampled from 15 grapevine plants. Thirteen endophytes isolated exclusively from grapevines that had shown phytoplasma symptoms, but then became asymptomatic (recovered plants), were retained (Table 1). All fungal genera were identified based on colony morphology on PDA medium and microscopic characteristics. The identifications were confirmed by the Centraalbureau voor Schimmelcultures Institute (the Netherlands). The 13 fungal endophytes belonged to the following genera: Alternaria, Aureobasidium, Arthrinium, Epicoccum, Leptosphaerulina, Nigrospora, Phoma, Phomopsis, and Schizophyllum. One isolate of $A$. pullulans (R6T4) and two isolates of E. nigrum (H2F1 and R11T3) were included. Voucher specimens have been deposited and stored in the culture collection of the Department of "Biologia e Protezione delle Piante", University of Udine, under codes reported in Table 1.

Amplification and sequencing. PCR with the universal primers ITS1 and ITS4 using high-molecular-weight DNA prepared from the 13 grapevine endophytes produced an amplicon of approximately 500 to $600 \mathrm{bp}$. The PCR products were sequenced and the sequence data were used to support identification by database

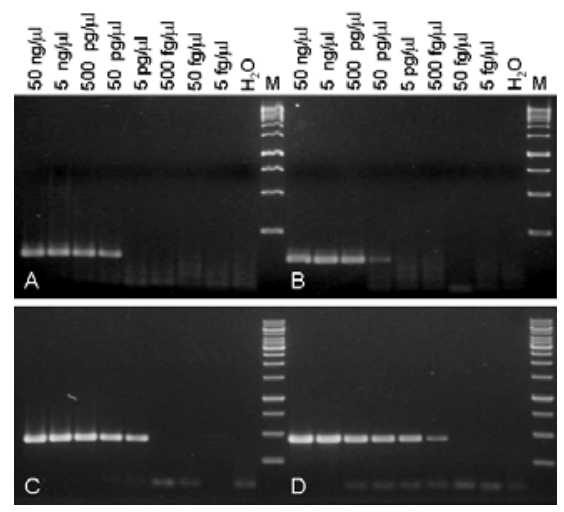

Fig. 2. Sensitivity of polymerase chain reaction (PCR) assays with primer pair Apu(R6T4)F2/R2 at 10 -fold serial dilutions $\mathbf{A}$, from $50 \mathrm{ng} / \mu$ to 5 $\mathrm{fg} / \mu \mathrm{l}$ in sterile water and $\mathbf{B}$, in $20 \mathrm{ng} / \mu \mathrm{l}$ of endophyte-free grapevine total genomic DNA; and with primers Eni(H2F1)F1/R1 at 10-fold serial dilutions C, from $50 \mathrm{ng} / \mu \mathrm{l}$ to $5 \mathrm{fg} / \mu \mathrm{l}$ in sterile water and $\mathbf{D}$, in $20 \mathrm{ng} / \mu \mathrm{l}$ of endophyte-free grapevine total genomic DNA. M: $1 \mathrm{~kb}$ DNA ladder. comparison. Isolate $\mathrm{H} 2 \mathrm{~F} 1$ had a sequence similarity of $99 \%$ with E. nigrum strain CBS 318.83 (GenBank accession no. AJ279448), and R11T3 had a sequence similarity of $100 \%$ with E. nigrum strains ATCC 62191 (GenBank accession no. FJ424241) and ATCC 32948 (GenBank accession no. FJ424240). The two E. nigrum strains $\mathrm{H} 2 \mathrm{~F} 1$ and R11T3 shared an ITS sequence similarity of $98 \%$. Isolate R6T4 had a $100 \%$ sequence similarity with A. pullulans var. pullulans strains CBS 584.75 (GenBank accession no. FJ150906), CBS 100524 (GenBank accession no. FJ150905), CBS 146.30 (GenBank accession no. FJ150902), and CBS 100280 (GenBank accession no. FJ150910).

Primer specificity and sensitivity. Primer pair Apu(R6T4)F2/R2 yielded an amplicon of the predicted size (135 bp) from extracted DNA of A. pullulans R6T4 isolated from grapevine and other $A$. pullulans strains from different sources (Table 1, Fig. 1A). Primer pair Eni(H2F1)F1/R1 yielded an amplicon of the predicted size (435 bp) from extracted DNA of E. nigrum $\mathrm{H} 2 \mathrm{~F} 1$ and R11T3 strains isolated from grapevine and other E. nigrum strains obtained from different sources (Table 1, Fig. 1B). DNA from other grapevine fungal endophytes did not amplify.

PCR amplification of the dilution series (ranging from $50 \mathrm{ng} / \mu \mathrm{l}$ to $5 \mathrm{fg} / \mu \mathrm{l}$ ) of purified DNA from A. pullulans R6T4 produced a visible product with $50 \mathrm{pg} / \mu \mathrm{l}$ when dilutions were prepared either with $20 \mathrm{ng} / \mu \mathrm{l}$ of total DNA from endophyte-free grapevine or with molecular grade water (Fig. 2A and B). PCR amplification of DNA from $E$. nigrum $\mathrm{H} 2 \mathrm{~F} 1$ produced a visible product with $5 \mathrm{pg} / \mu \mathrm{l}$ when dilutions were prepared with $20 \mathrm{ng} / \mu \mathrm{l}$ of total DNA from endophytefree grapevine (Fig. 2C) and with $500 \mathrm{fg} / \mu \mathrm{l}$ when dilutions were prepared with molecular grade water (Fig. 2D).

Detection of $A$. pullulans and $E$. nigrum in plant tissue. PCR of all of the DNA samples extracted from grapevine tissue yielded the expected PCR product for A. pullulans, and $86.4 \%$ of the samples yielded the expected amplicon for $E$. $n i$ grum (Fig. 3A and B). The two endophytes were obtained from grapevines that were symptomatic or asymptomatic for FD or from plants that had recovered from the disease. In direct-PCR, almost $100 \%$ of shoot samples (29/30) collected from different vineyards in Pordenone Province tested positive for the presence of A. pullulans (the remaining sample was positive in nested-PCR); whereas 20 out of the 30 samples tested positive for E. nigrum. Six out of 30 samples remained negative after nested-PCR with primers specific for $E$. nigrum. Eight out of 14 and nine out of 14 of the shoot samples from Montebelluna grapevines were positive for A. pullulans and $E$. nigrum, respectively, using directPCR. Nested-PCR successfully detected the fungi in the negative reactions by direct PCR.

RFLP analyses of specific PCR products were conducted to verify amplicon identity. RFLP profiles obtained with Tru1I and BsuRI on Apu(R6T4)F2/R2 PCR products from grapevine samples were identical to each other and to the A. pullulans R6T4 profile (Fig. 4A and B). RFLP analyses with Tru1I and Hin6I on Eni(H2F1)F1/R1 PCR products differentiated the two $E$. nigrum isolates from grapevines and all other isolates (Fig. 4C and D). The E. nigrum isolates were separated into two different groups (A and B) (Table 1). Group A was detected in 26 of 38 grapevine samples, group B was detected in 1 of 38 samples, and both groups were detected in 11 samples (Fig. 4C and D). The majority $(78 \%)$ of healthy and recovered plants hosted E. nigrum strains of RFLP group A, while the remaining plants hosted both groups. Group B isolates were not detected in any of the healthy or recovered plants. In diseased plants, E. nigrum RFLP groups $\mathrm{A}, \mathrm{A}+\mathrm{B}$, and $\mathrm{B}$ were detected in 53,40 , and $7 \%$ of the samples, respectively.

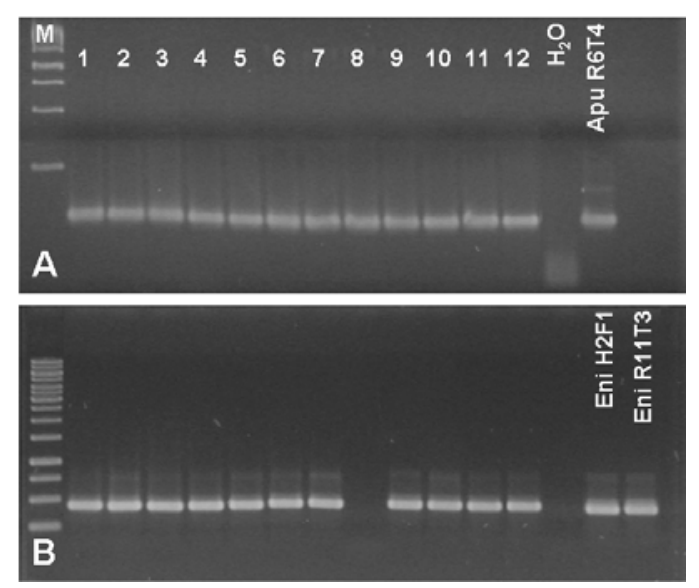

Fig. 3. Polymerase chain reaction (PCR) with species-specific primers A, Apu(R6T4)F2/R2 and B, Eni(H2F1)F1/R1 with DNA extracted from grapevine shoot tissue. Reference strains H6T4 for Aureobasidium pullulans and $\mathrm{H} 2 \mathrm{~F} 1$ and R11T3 for Epicoccum nigrum. Lanes 1 to 12: grapevine shoot samples collected in different locations in northeastern Italy. Lane M: 1 kb DNA ladder. 


\section{DISCUSSION}

Specific primers were developed here for the detection of $A$. pullulans and $E$. nigrum in grapevine tissues. These endophytes were present in high frequency in grapevines in northeastern Italy. The occurrence of both A. pullulans and E. nigrum in the same tissue has been reported $(21,30)$, indicating that these endophytes may coexist in a host (16). The specific primers amplified DNA from all tested $E$. nigrum and $A$. pullulans strains, including isolates from other sources. The primers did not amplify DNA from other fungal endophytes that are usually encountered during isolation attempts from grapevine tissues. PCR assays of both targets were highly sensitive; picogram quantities of DNA were suitable templates for A. pullulans, while femtogram quantities of DNA could be amplified for E. nigrum. The efficiency of the two species-specific PCR assays was not influenced by the presence of host plant DNA. Where the speciesspecific primers did not amplify target DNA, nested PCR was successfully used.

Two strains of $E$. nigrum were distinguished in this study. High genetic variability in E. nigrum populations unrelated to geographic origin has been well documented (2,3). In grapevines in Italy, one group was much more common, but both genotypes occasionally occurred in the same plant. This is noteworthy because the different distribution of $E$. nigrum RFLP groups was apparently associated with a particular disease status. However, the role of endophytic microorganisms in relation to phytoplasma infection and to the phenomena of spontaneous recovery from disease symptoms has still to be investigated.
Endophytic fungi may influence the microbial community within and on grapevines. For example, they may beneficially retard the establishment of wound pathogens such as $B$. cinerea (9), and some strains of $A$. pullulans are able to reduce ochratoxin accumulation in wine grapes by inhibiting Aspergillus spp. (6). Since microorganisms in grapes may influence wine quality, the association of endophytes such as $A$. pullulans and $E$. nigrum may play an important role in wine processing.

\section{ACKNOWLEDGMENTS}

This research was funded by the Italian Ministry for University and Research, PRIN Project prot. 2005074429. We thank Massimo Gardiman, CRAVIT Conegliano (TV), for micropropagated grapevine, and Gemma Assante, University of Milano, Salvatore Moricca, University of Firenze, Marinella Rodolfi, University of Pavia, Gianfranco Romanazzi, University of Marche, and Serena Moruzzi, University of Udine, for providing $A$. pullulans and E. nigrum isolates. We are grateful to Laurence Cantrill for English text revision.

\section{LITERATURE CITED}

1. Andrews, J. H., Harris, R. F., and Nordheim, E. V. 2002. Population biology of Aureobasidium pullulans on apple leaf surface. Can. J. Microbiol. 48:500-513.

2. Arenal, F., Platas, G., Martin, J., Salazar, O., and Peláez, F. 1999. Evaluation of different PCR-based fingerprinting techniques for assessing the genetic variability of isolates of the fungus Epicoccum nigrum. J. Appl. Microbiol. 887:898-906.

3. Arenal, F., Platas, G., and Peláez, F. 2004. Taxonomic reconsideration of Epicoccum nigrum and Phoma epicoccina based on DNA sequences and morphological observations. Mycotaxon 89:465-471

4. Arnold, A. E. 2007. Understanding the diversity of foliar endophytic fungi: Progress, challenges, and frontiers. Fungal Biol. Rev. 21:5166.

5. Campanile, G., Campanile, D., Nigro, M.,
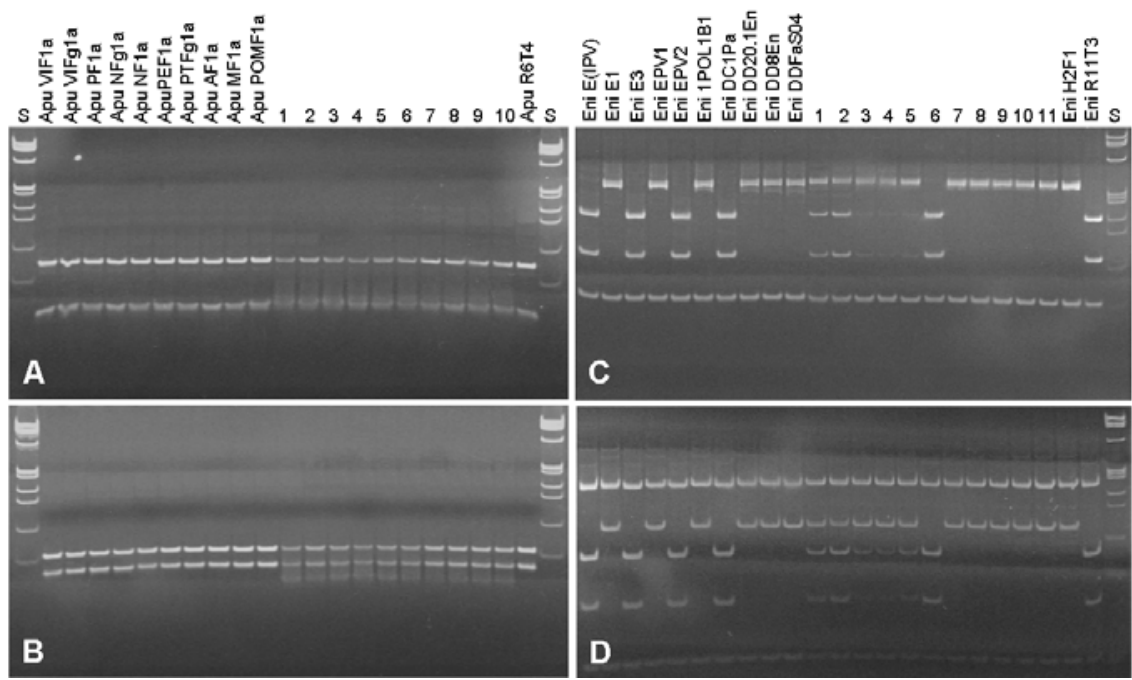

Fig. 4. Restriction fragment length polymorphism (RFLP) analyses with restriction enzymes A, Tru1I and $\mathbf{B}, B s u$ RI on polymerase chain reaction (PCR) products Apu(R6T4)F2/R2; C, Tru1I and D, Hin6I on PCR products Eni(H2F1)F1/R1. RFLP products were separated by electrophoresis through an $8 \%$ polyacrylamide gel. Apu: Aureobasidium pullulans, Eni: Epicoccum nigrum. Reference strains are H6T4 for A. pullulans and H2F1 (RFLP group A) and R11T3 (RFLP group B) for E. nigrum. Lanes 1 to 11: grapevine shoot samples collected in different locations in northeastern Italy. Lane S: $\Phi 174$ Hae III digested (New England BioLabs, USA; fragment sizes [bp] from top to bottom: 1,353, 1,078, 872, 603, 310, 281, 271, 234, 194, 118, 72).
Mannerucci, F., Ruscelli, A., and Luisi, N. 2006. Prove preliminari di antagonismo di funghi endofiti contro Diplodia corticola e indicazioni gestionali per il contenimento del deperimento delle querce. Foresta 3(1):78-85.

6. de Felice, D. V., Solfrizzo, M., De Curtis, F., Lima, G., Visconti, A., and Castoria, R. 2008. Strains of Aureobasidium pullulans can lower ochratoxin A contamination in wine grapes. Phytopathology 98:1261-1270.

7. Doss, R. P., Clement, S. L., Kuy, S.-R., and Welty, R. E. 1998. A PCR-based technique for detection of Neotyphodium endophytes in diverse accessions of tall fescue. Plant Dis. 82:738-740.

8. Doyle, J. J., and Doyle, J. L. 1990. Isolation of plant DNA from fresh tissue. Focus 12:13-15.

9. Dugan, F. M., Lupien, S. L., and Grove, G. G. 2002. Incidence, aggressiveness and in planta interactions of Botrytis cinerea and other filamentous fungi quiescent in grape berries and dormant buds in Central Washington State. J. Phytopathol. 150:375-381.

10. Elmer, P. A. G., Alcock, E. A., and Parry, F. 2001. Epicoccum nigrum as a biological control and as a source of antimicrobial metabolites. Page 339 in: Proc. Bienn. Conf. Australas. Plant Pathol. Soc. 13th. Cairns, Australia.

11. Elmer, P. A. G., and Reglinski, T. 2006. Biosuppression of Botrytis cinerea in grapes. Plant Pathol. 55:155-177.

12. Fleet, G. H., Prakitchaiwattana, C., Beh, A. L., and Heard, G. 2002. The yeast ecology of wine grapes. Pages 1-17 in: Biodiversity and Biotechnology of Wine Yeasts. M. Ciani, ed. Research Signpost, Kerala, India.

13. Fowler, S. R., Jaspers, M. V., Walter, M., and Stewart, A. 1999. Suppression of overwintering Botrytis cinerea inoculum on grape rachii using antagonistic fungi. N.Z. Plant Prot. 52:141-147.

14. Garbeva, P., van Overbeek, L. S., van Wuurde, J. W. L., and van Elsas, J. D. 2001. Analysis of endophytic bacterial communities of potato by plating and denaturing gradient gel electrophoresis (DGGE) of 16S rDNA based PCR fragments. Microb. Ecol. 41:369-383.

15. Gardes, M., and Bruns, T. D. 1993. ITS primers with specificity for basidiomycetes: Application to the identification of mycorrhizae and rust. Mol. Ecol. 2:113-118.

16. Gimenez, C., Cabrera, R., Reina, M., and Gonzales-Coloma, A. 2007. Fungal endophytes and their role in plant protection. Curr. Org. Chem. 11:707-720.

17. Hill, R., Eden, M. A., Cutler, H. G., Elmer, P. A. G., Reglinski, T., and Parker, S. R. 1999 Practical natural solutions for plant disease control. Pages 201-210 in: Biologically Active Natural Products: Agrichemical. H. Cutler and S. Cutler eds. CRC Press, Boca Raton, FL.

18. Ippolito, A., Nigro, F., Romanazzi, G., and Campanella, V. 1997. Field application of Aureobasidium pullulans against Botrytis storage rot of strawberry. Atti: Joint Workshop COST 914 - COST 915. Non conventional methods for the control of post-harvest disease and microbiological spoilage - Bologna, 9-11 ottobre, 127-133.

19. Kavroulakis, N., Ntougias, S., Zervakis, G. I., Ehaliotis, C., Haralampidis, K., and Papadopoulou, K. K. 2007. Role of ethylene in the protection of tomato plants against soil-borne fungal pathogens conferred by an endophytic Fusarium solani strain. J. Exp. Bot. 29:1-12.

20. Kortekamp, A. 1997. Epicoccum nigrum Link: A biological control agent of plasmopara viticola (Berk. et Curt.) Berl. et De Toni? Vitis 36: 215-216.

21. Lacava, P. T., Araújo, W. L., Marcon, J., Maccheroni, W., Jr., and Azevedo, J. L. 2004. Interaction between endophytic bacteria from citrus plants and the phytopathogenic bacteria 
Xylella fastidiosa, causal agent of citrusvariegated chlorosis. Lett. Appl. Microbiol. 39:55-59.

22. Larena, I., De Cal, A., Linan, M., and Melgarejo, P. 2003. Drying of Epicoccum nigrum conidia for obtaining a shelf-stable biological product against brown rot disease. J. Appl. Microbiol. 94:508-514.

23. Lecellier, G., and Silar, P. 1994. Rapid method for nucleic acid extraction from Petri dishgrown mycelia. Curr. Genet. 25:122-123.

24. Madrigal, C. Tadeo, J. L., and Melgarejo, P. 1991. Relationship between flavipin production by Epicoccum nigrum and antagonism against Monilinia laxa. Mycol. Res. 95:13751381.

25. Malvick, D. K., and Grunden, E. 2005. Isolation of fungal DNA from plant tissues and removal of DNA amplification inhibitors. Mol. Ecol. Notes 5:958-960.

26. Musetti, R., Marabottini, R., Badiani, M., Martini, M., Sanità di Toppi, L., Borselli, S., Borgo, M., and Osler, R. 2007. On the role of $\mathrm{H}_{2} \mathrm{O}_{2}$ in the recovery of grapevine (Vitis vinifera, cv. Prosecco) from Flavescence dorée disease. Funct. Plant Biol. 34:750-758.

27. Nigro, F., Ippolito, A., Schena, L., Pentimene, I., and Logorio, A. 2003. Control of postharvest rots of sweet cherries and table grapes with endophytic isolates of Aureobasidium pullulans. Postharv. Biol. Tec. 30:209-220.

28. Pouliot, J. M., Walton, I., Parkhouse, M. N.,
Abu-Lail, L. I., and Camesano, T. A. 2005. Adhesion of Aureobasidium pullulans is controlled by uronic acid based polymers and pullulan. Biomacromolecules 6:1122-1131.

29. Prasongsuk, S., Sullivan, R. F., Kuhirun, M., Eveleigh, D. E., and Punnapayak, H. 2005. Thailand habitats as source of pullulanproducing strains of Aureobasidium pullulans. World J. Microb. Biot. 21:393-398.

30. Rodolfi, M., Legler, S. E., and Picco, A. M. 2006. Endofiti fungini in Vitis vinifera in Oltrepò Pavese. Micol. Italiana 35:25-31.

31. Rozen, S., and Skaletsky, H. J. 2000. Primer3 on the WWW for general users and for biologist programmers. Pages 365-386 in: Bioinformatics Methods and Protocols: Methods in Molecular Biology. S. Krawetz and S. Misener, eds. Humana Press, Totowa, NJ.

32. Saikkonen, K., Faeth, S. H., Helander, M., and Sullivan, T. J. 1998. Fungal endophytes: A continuum of interactions with host plants. Annu. Rev. Ecol. Syst. 29:319-343.

33. Schena, L., Ippolito, A., Zahavi, T., Cohen, L., Nigro, F., and Droby, S. 1999. Genetic diversity and biocontrol activity of Aureobasidium pullulans isolates against postharvest rots. Postharv. Biol. Tec. 17:189-199.

34. Schena, L., Nigro, F., Pentimone, I., Ligorio, A., and Ippolito, A. 2003. Control of postharvest rots of sweet cherries and table grapes with endophytic isolates of Aureobasidium pullulans. Postharv. Biol. Tec. 30:209-220.
35. Sessitsch, A., Reiter, B., Pfeifer, U., and Wilhelm, E. 2002. Cultivation-independent population analysis of bacterial endophytes in three potato varieties based on eubacterial and Actinomycetes-specific PCR of 16S rRNA genes. FEMS Microbiol. Ecol. 39:23-32.

36. Takesako, K., Ikai, K., Haruna, F., Endo, M., Shimanaka., K., Sono, E., Nakamura, T., Kato, I., and Yamaguchi, H. 1991. Aureobasidins, new antifungal antibiotics. Taxonomy, fermentation, isolation and properties. J. Antibiot. 44:919-924

37. Vizzuso, C., Turco, E., Dellavalle, I., Ragazzi, A., and Moricca, S. 2007. Interazioni antagonistiche in vitro fra Phomopsis quercina funghi endofitici di specie quercine. Micologia Italiana XXXVI, n. 2., 30-38.

38. White, T. J., Bruns, T., Lee, S., and Taylor, J. 1990. Amplification and direct sequencing of fungal ribosomal RNA genes for phylogenetics. Pages 315-322 in: PCR Protocols: A Guide to Methods and Applications. M. A. Innes, D. H. Gelfand, J. J. Sninsky, and T. J. White, eds. Academic Press, San Diego, CA.

39. Yurlova, N. A., de Hoog, G. S., and Gerrits van den Ende, A. H. G. 1999. Taxonomy of Aureobasidium and allied genera. Stud. Mycol 43:63-69.

40. Zalar, P., Gostinčar, C., de Hoog, G. S., Uršič, V., Sudhadham, M., and Gunde-Cimerman, N. 2008. Redefinition of Aureobasidium pullulans and its varieties. Stud. Mycol. 61:21-38. 